\title{
NASZ KATEDRALNY NESTOR
}

\section{Wojciech Drożdż}

Wydział Zarządzania i Ekonomiki Usług, Uniwersytet Szczeciński

Jako katedra mamy bodaj najdłuższy staż na naszym wydziale, a zważywszy na naszą historyczną specyfikę - gospodarkę morską, można śmiało powiedzieć, że jesteśmy jednostką unikatową w skali kraju. Nazwa katedry ewaluowała kilkakrotnie, aby osiągnąć ostatecznie odniesienie do gospodarki światowej i transportu morskiego. Katedra to przede wszystkim konkretni ludzie (naukowcy i dydaktycy), wśród których primus inter pares z pewnością jest i pozostanie Profesor Franciszek Gronowski.

Nie do przecenienia jest Jego wkład w rozwój myśli ekonomicznej w zakresie gospodarki morskiej, zarówno w skali Szczecina i Pomorza Zachodniego, jak i całego kraju. Jego wieloletnia, owocna praca naukowa i dydaktyczna w Wyższej Szkole Ekonomicznej w Szczecinie, Politechnice Szczecińskiej i wreszcie Uniwersytecie Szczecińskim zasługuje na najwyższe uznanie społeczności akademickiej, a w szczególności uczelni i wydziałów zajmujących się naukowo szeroko rozumianą gospodarką morską.

Dla naszej katedry jest on niedoścignionym wzorem talentu naukowego, taktu i życzliwości wobec ludzi i świata Go otaczającego, a także swoistej dobroduszności, połączonej z wielkim poczuciem humoru. Pomimo upływu lat Profesor trwa w swojej otwartości i chęci pomocy wszystkim, którzy się do Niego zgłaszają, zwykle okraszając rozmowy wiązanką żartów i anegdot.

Miałem zaszczyt i przyjemność poznać Profesora podczas Sejmiku Morskiego w Grzybowie koło Kołobrzegu, gdzie nie tylko był jednym z głównych uczestników dyskusji panelowych, ale także prowodyrem wspólnego biesiadowania połączonego ze śpiewem.

W październiku 2001 roku zostałem zatrudniony na stanowisku asystenta w naszej katedrze. Dopiero po kilku latach dowiedziałem się, że to między innymi dzięki poparciu Profesora Franciszka w procedurze konkursowej mogłem dołączyć do zespołu katedralnego. Do dziś bardzo wdzięczną pamięcią obejmuję wsparcie, jakiego udzielił mi w pierwszych latach mojej pracy w katedrze, faktycznie sprawując rolę Mentora. Mimo że był już wtedy Profesorem Seniorem nie szczędził nam - młodym pracownikom nauki - sił i czasu na pomoc merytoryczną dotyczącą pisania prac doktorskich czy iście ojcowskie, zwyczajne z pozoru rozmowy o trudach dnia codziennego. Był dobrym duchem katedry wielokrotnie rozładowując rodzące się napięcia pomiędzy szefostwem, a resztą zespołu.

Z moim serdecznym przyjacielem prof. Michałem Plucińskim - najmłodszym i jednym z najwybitniejszych wychowanków Profesora Franciszka - niejednokrotnie wspominamy 
z uśmiechem nasze wspólne eskapady pod przywództwem Nestora. Były to wyjazdy do Trójmiasta i Elbląga na Sejmiki Morskie, rejsy promowe przez Bałtyk, a także katedralna wyprawa na wędkarski weekend.

Podczas tego ostatniego wyjazdu, Profesor Gronowski, a któżby inny (!) stał się szczęśliwym posiadaczem sporego węgorza. Niestety ryba pozostawiona w siatce na noc wyślizgnęła się z potrzasku i po godzinie 4 nad ranem do śpiących w domku campingowym kolegów dobiegł krzyk Profesora: Michał, Zenek, Wojtek węgorz uciekł! Szukajcie węgorza!

To tylko jedna z zabawnych sytuacji, która wywołuje uśmiech na twarzach kolegów z katedry. Takie spontaniczne reakcje Profesora sprawiają, że Jego pojawienie się na kolejnej konferencji, seminarium czy uroczystości wydziałowej powoduje natychmiastową poprawę nastroju.

Dziś, choć powrócił do swych rodzinnych stron, w niedalekiej odległości od historycznej stolicy Kujaw - Inowrocławia, nadal pozostaje w kontakcie z pracownikami swojej katedry, z czego jesteśmy niezmiernie dumni. Jego dziedzictwo naukowe godnie przejął i rozwija w ramach Zakładu Transportu Morskiego i Lotniczego prof. Michał Pluciński, a mnie kierującemu Katedrą Gospodarki Światowej i Transportu Morskiego pozostaje wyrazić szczere życzenie, aby NASZ KATEDRALNY NESTOR jeszcze częściej odwiedzał swoich dawnych współpracowników, a za 10 lat, aby wszyscy w dobrym zdrowiu świętowali Stulecie Urodzin Profesora, śmiejąc się z Jego żartów i śpiewając zainicjowane przez Niego piosenki. 